\title{
Cemp1-p3 Peptide Promotes the Transformation of Octacalcium Phosphate into Hydroxyapatite Crystals
}

\author{
Maricela Santana ${ }^{1}$, Gonzalo Montoya ${ }^{1}$, Raúl Herrera ${ }^{2}$, Lía Hoz ${ }^{1} @$, Enrique Romo ${ }^{1}$, \\ Claudia Zamora ${ }^{1}\left(\mathbb{D}\right.$, Ana Wintergerst ${ }^{1}$ and Higinio Arzate ${ }^{1, *(\mathbb{D})}$ \\ 1 Laboratorio de Biología Periodontal y Tejidos Mineralizados, Facultad de Odontología, \\ Universidad Nacional Autónoma de México, Mexico City 04510, Mexico; \\ m.santana.vazquez@gmail.com (M.S.); jimago_jar@hotmail.com (G.M.); lahry@hotmail.com (L.H.); \\ dr_roaren@yahoo.com.mx (E.R.); patpedrazamora@gmail.com (C.Z.); anawintergerst@yahoo.com (A.W.) \\ 2 Instituto de Física, Universidad Nacional Autónoma de México, Mexico City 04510, Mexico; \\ rherrera@fisica.unam.mx \\ * Correspondence: harzate@unam.mx
}

Received: 11 November 2020; Accepted: 10 December 2020; Published: 11 December 2020

\begin{abstract}
Dental cementum contains unique molecules that regulate the mineralization process in vitro and in vivo, such as cementum protein 1 (CEMP1). This protein possesses amino acid sequence motifs like the human recombinant CEMP1 with biological activity. This novel cementum protein 1-derived peptide (CEMP1-p3, from the CEMP1's N-terminal domain: (QPLPKGCAAVKAEVGIPAPH), consists of 20 amino acids. Hydroxyapatite (HA) crystals could be obtained through the combination of the amorphous precursor phase and macromolecules such as proteins and peptides. We used a simple method to synthesize peptide/hydroxyapatite nanocomposites using OCP and CEMP1-p3. The characterization of the crystals through scanning electron microscopy (SEM), powder X-ray diffraction (XRD), high-resolution transmission electron microscopy (HRTEM), and Raman spectroscopy revealed that CEMP1-p3 transformed OCP into hydroxyapatite (HA) under constant ionic strength and in a buffered solution. CEMP1-p3 binds and highly adsorbs to OCP and is a potent growth stimulator of OCP crystals. CEMP1-p3 fosters the transformation of OCP into HA crystals with crystalline planes (300) and (004) that correspond to the cell of hexagonal HA. Octacalcium phosphate crystals treated with CEMP1-p3 grown in simulated physiological buffer acquired hexagonal arrangement corresponding to HA. These findings provide new insights into the potential application of CEMP1-p3 on possible biomimetic approaches to generate materials for the repair and regeneration of mineralized tissues, or restorative materials in the orthopedic field.
\end{abstract}

Keywords: crystal growth; octacalcium phosphate; hydroxyapatite; cementum protein 1 (CEMP1); peptides; mineralization

\section{Introduction}

Cementum is a mineralized tissue that covers the root; it possesses unique molecules that promote cell proliferation and differentiation of periodontal ligament cells [1]. One of these molecules; cementum protein 1 (CEMP1), which is synthesized by cementoblasts, nucleates hydroxyapatite crystals in vitro [2] and has been shown to be a cementum-specific marker and to promote bone regeneration in vivo [3]. The characterization of CEMP1 shows that it is a glycosylated, phosphorylated, and thermostable protein [4]. Human recombinant CEMP1 plays a role in the development of the periodontium, which surrounds and supports the teeth by promoting the differentiation of multipotent cells from the periodontal ligament into cementoblasts that form cementum [1,5,6]. It binds hydroxyapatite and may promote the biomineralization of cementum [7]. The control of crystal nucleation and growth has 
numerous consequences to understand the basic mechanism of biomineralization. It has recently been found that CEMP1's N-terminus-derived peptide (CEMP1-p1) promotes differentiation of periodontal ligament cells toward a mineralizing-like phenotype more importantly, the bioactive peptide shows osteoinductive and osteogenic properties in vivo $[4,8]$.

Apatites and related calcium phosphates have been of considerable interest to biologists, mineralogists, and inorganic and industrial chemists for many years (Hench, 2005). The reasons for this are clear: apatites form the mineral component of bones and teeth, and calcium phosphates are also involved in several mineralization processes, including those that occur in pathological calcifications [9-12]. The great versatility of apatites in accepting a large variety of substitutional ions, complicates their study $[13,14]$. The role of octacalcium phosphate (OCP: $\left.\mathrm{Ca}_{8} \mathrm{H}_{2}\left(\mathrm{PO}_{4}\right)_{6} \cdot 5 \mathrm{H}_{2} \mathrm{O}\right)$ in bone formation remains inconclusive. OCP is thermodynamically less stable than hydroxyapatite, and it is often found as an intermediate phase during the precipitation of $\mathrm{HA}\left(\mathrm{Ca}_{10}\left(\mathrm{PO}_{4}\right)_{6}(\mathrm{OH})_{2}\right)$. However, it provides a rational basis for understanding physiologically important phenomena such as the unusual variability in the stoichiometry of apatite precipitates, and the origin of ribbonlike and platy morphologies of biological apatite crystallites, a possible mechanism for the incorporation of impurities and defects into mineralized tissues [15].

The control of crystal nucleation and growth has numerous consequences for understanding the basic mechanism of biomineralization. Experimental evidence indicates that specific molecular interactions at inorganic-organic interfaces can result in the controlled nucleation and growth of inorganic crystals $[16,17]$. Therefore, the purpose of this study was to determine the affinity of CEMP1-p3 for OCP crystals and if it promotes the growth and transformation to hydroxyapatite (HA) crystals in vitro.

\section{Materials and Methods}

\subsection{Peptide Synthesis}

The synthetic peptides used in this study correspond to the amino acids 51 to 70 of CEMP1's N-terminal domain: QPLPKGCAAVKAEVGIPAPH (CEMP1-p3). The peptide was synthesized by New England Peptide, Ipswich, MA, USA, 01938, as described elsewhere [4] with standard solid-phase (Fmoc) peptide synthesis techniques. The peptides were purified by C-18 reversed-phase liquid chromatography up to $>90 \%$ purity (New England Peptide, Ipswich, MA, USA). The peptide has a mass of $1983.38 \mathrm{Da}$. The lyophilized peptide was dissolved in deionized water at room temperature. All solutions were filtered $(0.22 \mu \mathrm{m}$ filter) before use. The isoelectric point (pI), hydrophobic character and GRAVY of CEMP1-p3 were determined by the ExPASy tool ProtParam; https://web.expasy.org/protparam/. Quartier Sorge-Batiment Amphipole 1015 Lausane/Switzerland. The molecular order of CEMP1-p3 was analyzed with GlobPlot 2.3 software. (EMBL) Meyerhofstraße 69117, Heilderberg, Germany.

\subsection{Synthesis of Octacalcium Phosphate Crystals by Co-Precipitation}

Octacalcium phosphate samples were prepared using a homogeneous co-precipitation method. In brief, a solution containing $64 \mathrm{mM}$ calcium acetate $\left(\mathrm{Ca}\left(\mathrm{CH}_{3} \mathrm{COO}\right)_{2}\right)$ was drip mixed with a solution containing $16 \mathrm{mM}$ sodium hydrogen phosphate $\left(\mathrm{Na}_{2} \mathrm{HPO}_{4}\right)$ and $16 \mathrm{mM}$ sodium dihydrogen phosphate $\left(\mathrm{NaH}_{2} \mathrm{PO}_{4}\right)$, vigorously stirred at $60{ }^{\circ} \mathrm{C}$ for $2 \mathrm{~h}$. Subsequently, the sample was washed three times with deionized $\mathrm{H}_{2} \mathrm{O}$. After this step, the container with the final solution was introduced into liquid nitrogen $(77 \mathrm{~K})$ to flash-freeze the solution, and then lyophilized for $24 \mathrm{~h}$ to obtain a fine powder for further characterization.

\subsection{Binding of CEMP1-p3 to OCP Crystals}

CEMP1-p3 was labeled with Alexa fluorochrome AF-488 (Thermo Fisher Scientific Carlsbad, CA, USA), following the manufacturer's recommendations. Five $\mu \mathrm{L}$ of Alexa Fluor $488 / 546$ in 
dimethylformamide were added to $200 \mu \mathrm{L}$ of CEMP1-p3 at a concentration of $10 \mu \mathrm{g} / \mu \mathrm{L}$ plus $20 \mu \mathrm{L}$ of sodium bicarbonate $(1 \mathrm{M})$. The solution was incubated for $1 \mathrm{~h}$ at room temperature. Unconjugated label was removed by dialysis with four changes of 2L of Tris-buffered saline, $\mathrm{pH} 7.4$, for $4 \mathrm{~h}$ each using 1.0-kDa dialysis tubing (Spectrum Laboratories Inc., Rancho Dominguez, CA, USA). After freeze-drying, the samples were stored at $-20^{\circ} \mathrm{C}$ until use. Confocal microscopy was used to evaluate the fluorescence-labeled peptide adsorbed by oxalate crystals. OCP crystals were incubated with Alexa Fluor 488-labeled peptide in TBS solution. The solution was stirred for $30 \mathrm{~min}$ in a dark environment. OCP solution was centrifuged (with bound peptide) to settle; supernatants were removed and collected. The pellets were washed to remove any unbound peptide. Then, TBS-EDTA was added to OCP powder to measure fluorescence in the supernatants with a fluorescence spectrophotometer (FilterMax F5, Molecular Devices, San Jose, CA, USA) at an excitation wavelength of $556 \mathrm{~nm}$ to estimate the concentration of bound and unbound labeled peptide in both solutions. Dissociation constants of relative binding of CEMP1-p3 to OCP with a known surface area were calculated. The kd value, (in $\mu \mathrm{M}$ ) Bmax value (in $\mu \mathrm{g}$ ), and R2 value were calculated with GraphPad Prism 4 (San Diego, CA, USA), plotting the average free peptide $(\mu \mathrm{M})$ vs. average bound CEMP1-p3 $(\mu \mathrm{g})$.

\subsection{Octacalcium Phosphate Constant Composition Seeded Growth (CCSG) Assays}

Nancollas's method [18] was utilized using a computer-assisted TIM856 titration manager (Radiometer Analytical, Hach, Manchester, UK) the addition of the titrant based on the set $\mathrm{pH}$ value. The reaction solution contained $150 \mathrm{mM} \mathrm{NaCl}, 1.7 \mathrm{mM} \mathrm{Ca}\left(\mathrm{NO}_{3}\right)_{3}, 1.7 \mathrm{mM} \mathrm{Na}_{2} \mathrm{HPO}_{3}$, and $2.5 \mathrm{mM}$ $\mathrm{NaOH}$. After adding $2 \mathrm{mg}$ of OCP seed crystal slurry, $\mathrm{pH}$ was adjusted to 7.4 and maintained for $4 \mathrm{~h}$. The reaction vessel was sealed, and the temperature was maintained at $37^{\circ} \mathrm{C}$. Different doses of CEMP1-p3 $(0.6,0.7,1.25,1.75,2.75$, and $3.75 \mu \mathrm{g})$ were added after $\sim 6 \mathrm{~min}$ of crystal growth.

\subsection{Characterization of the Mineral Deposits}

\subsubsection{Scanning Electron Microscopy}

The morphology, microstructure, and the elemental chemical composition of the precipitates were examined with JSM-7800F Schottky FE-SEM. The control and experimental samples were mounted on double-sided conductive carbon tape fixed onto an aluminum specimen holder. The elemental analysis was performed at $20-25 \mathrm{kV}$ acceleration voltage and at 20-25 Pa of pressure in the specimen chamber on different areas with different probe sizes. The images were obtained with backscattered electron signal (BSE). The calcium to phosphate $(\mathrm{Ca} / \mathrm{P})$ ratio was calculated from the intensity of the peaks present in the EDS pattern and the semi-quantitative analysis obtained by EDS (Norman X-ray microanalysis detector, Voyager model 4.2.3: Creative electron, San Marcos, CA, USA).

\subsubsection{Transmission Electron Microscopy}

The composite CEMP1-p3-OCP was characterized by transmission electron microscopy (JEOL JEM-2010F FasTEM microscope) operated at $200 \mathrm{kV}$, with an ultrahigh-resolution polepiece with an accelerating voltage of $200 \mathrm{kV}$ and a $0.19 \mathrm{~nm}$ resolution. The calcium phosphate precipitates were suspended in isopropyl alcohol and dispersed by ultrasonic bath, then a drop was placed on carbon Formvar-coated $\mathrm{Cu}$ grids with a 300 mesh.

\subsubsection{High Resolution Transmission Electron Microscopy (HRTEM)}

Digital Micrograph software was used in order to analyze the crystal structure of the samples. The interplanar distances were compared to standard hydroxyapatite (JCPDS 72-1243. 2001). 


\subsubsection{Micro Raman Spectra}

Raman spectra were recorded on a confocal microscope (Thermo Scientific, Waltham, MA, USA) equipped with micro-Raman with an excitation source of $532 \mathrm{~nm}(2.33 \mathrm{eV})$. Measurements were carried out in the $50-3000 \mathrm{~cm}^{-1}$ range.

\section{Results}

\subsection{Synthesis and Characterization of Octacalcium Phosphate Crystals}

Octacalcium phosphate crystalizes in the triclinic system, with $\mathrm{P}-1 \mathrm{C}_{\mathrm{i}}{ }^{1}$ group. The chemical composition of OCP consists of a two-layer structure. It has an apatite layer between $\mathrm{HPO}_{4}-\mathrm{OH}$ layers along the a-axis. There are six $\mathrm{PO}_{4}$ molecules (P1-P6) in the OCP unit. P1-P4 are in the apatite layer, and $\mathrm{P} 5$ and $\mathrm{P} 6$ are in the $\mathrm{HPO}_{4}-\mathrm{OH}$ layers (Supplementary material, Figure S1). All $\mathrm{PO}_{4}$ molecules in the OCP unit are conjugated to specific $\mathrm{Ca}^{2+}$ ions in the OCP unit [13]. The morphological analysis of the sample was obtained by scanning electron microscopy that shows a series of micrographs of different areas and amplification. Crystals display a homogeneous morphology made up of triangular-shaped platelets with an average size of $1.3 \mu \mathrm{m}$ (Figure 1A). The chemical analysis (EDS) yielded a $\mathrm{Ca} / \mathrm{P}=1.34$ ratio, which is very close to a stoichiometric phase of OCP (Figure 1B).

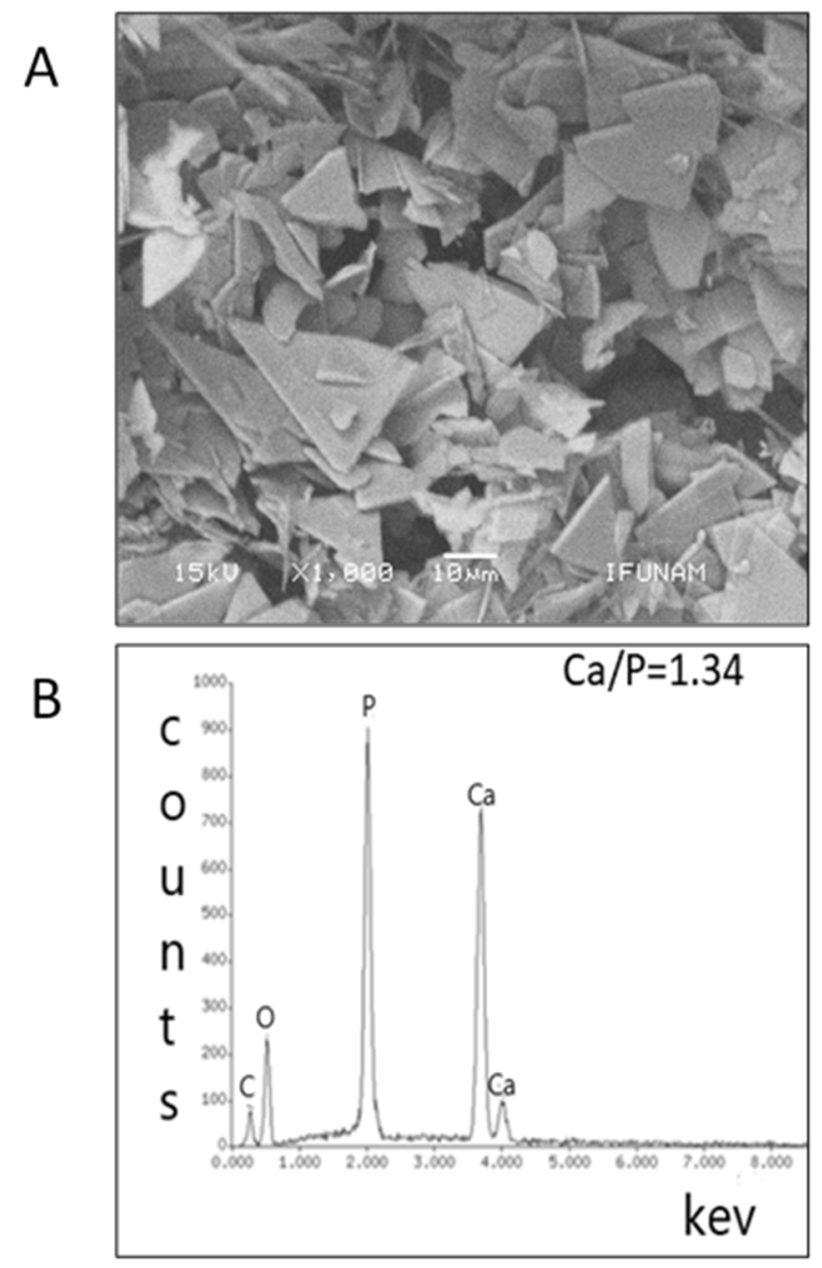

Figure 1. Scanning electron microscopy (SEM) images of OCP crystals obtained by co-precipitation. Agglomerated OCP crystals with an average size of $1.3 \mu \mathrm{m}$ (A). EDS analysis of OCP crystals $\mathrm{Ca} / \mathrm{P}=1.34$ ratio $(\mathbf{B})$. 
The samples were analyzed by transmission electron microscopy (TEM) to obtain a detailed study at the nanostructural level. TEM analysis of OCP crystals shows a series of low and high magnification micrographs which display OCP in crystalline-like platelet morphology: despite bubble defects in the crystals due to the interaction of the electron beam (Figure 2A,B), we observed, the typical interplanar distance $\mathrm{d}=0.55 \mathrm{~nm}$ for OCP corresponding to the crystalline plane (1-11) as determined by fast Fourier transform (FFT) (Figure 2C).
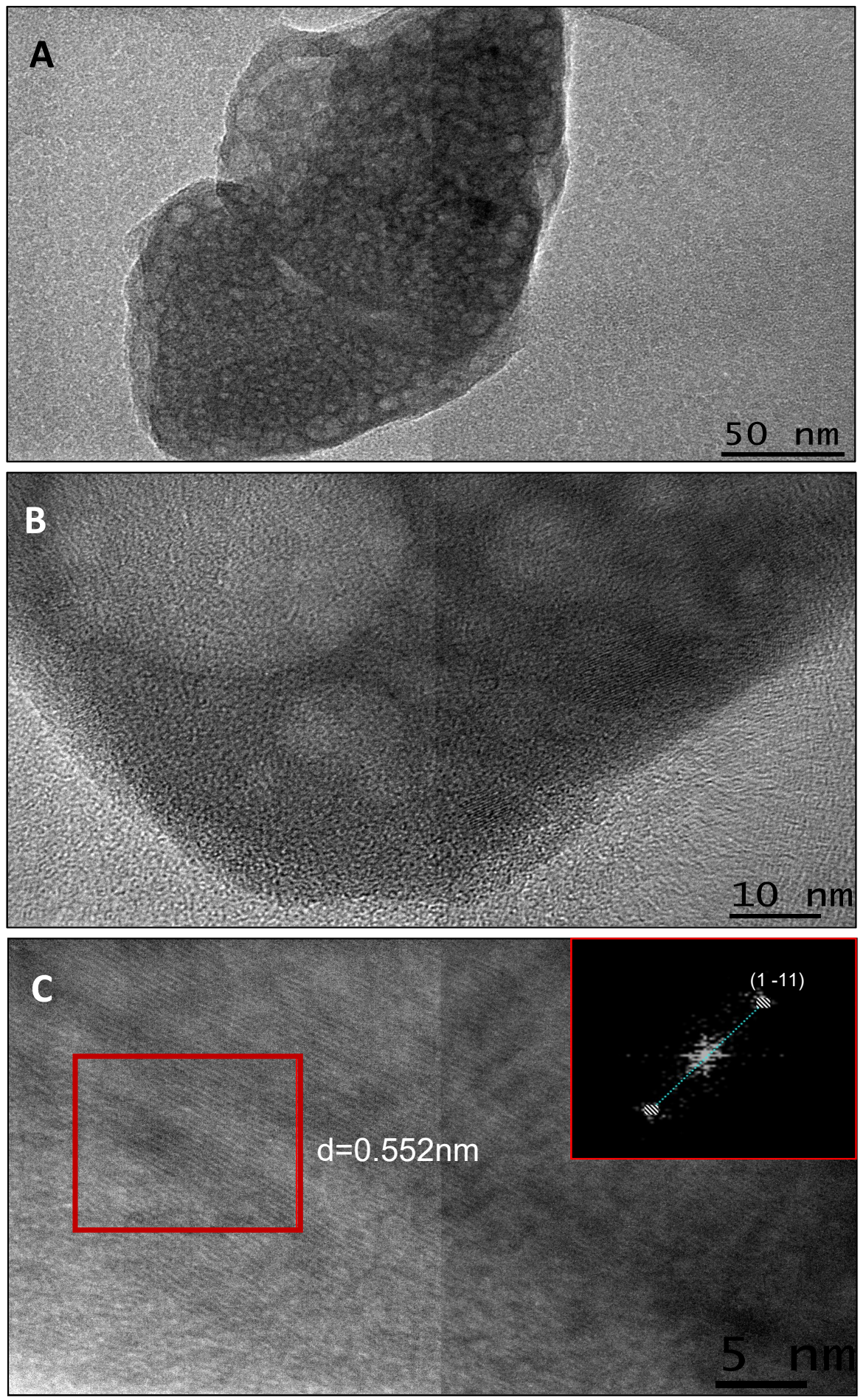

Figure 2. TEM micrographs of synthetic OCP crystals platelets, $(\mathbf{A}, \mathbf{B})$ Bubble-like defects revealed in a bright-field TEM image of OCP platelets, (C). HRTM image of OCP and its corresponding FFT analysis (inset). 
The Raman spectrum shows frequencies of vibrational modes of $\mathrm{OCP}$, in which a robust $\mathrm{v} 1$ band dominates at $957 \mathrm{~cm}^{-1}$ due to the symmetric stretching of functional groups $\mathrm{PO}_{4}{ }^{3-}$ (Figure $3 \mathrm{~A}$ ). A signal is distinguished at $879 \mathrm{~cm}^{-1}$ due to the functional group $\mathrm{HPO}_{4}{ }^{2-}((\mathrm{P} 5)$ which is located in the hydrated layer of the network, the stretching $\mathrm{P}-(\mathrm{OH}) \mathrm{v} 1)$ at $917 \mathrm{~cm}^{-1}$ due to the presence of the functional group $\mathrm{HPO}_{4}{ }^{2-}((\mathrm{P} 6)$ located between the apatite layer and the hydrated layer. Two more signals are distinguished, one at $1005 \mathrm{~cm}^{-1}\left(\mathrm{HPO}_{4}{ }^{2-} \mathrm{v} 1 \mathrm{stretch}\right)$ and another at $1109 \mathrm{~cm}^{-1}\left(\mathrm{HPO}_{4}{ }^{2-} \mathrm{v} 3\right.$ stretch) (Figure 3A), [19]. The X-ray diffractogram of the crystals obtained shows that the crystalline phase corresponds to OCP according to ICPDS card No. 44-0778 with a triclinic unit cell and space group P-1. The main peaks correspond to the crystal planes (100) located at $4.7^{\circ}$; the two peaks at $31.4^{\circ}$ and $31^{\circ}$ correspond to the crystal planes (420) and (-710) (Figure 3B).

A

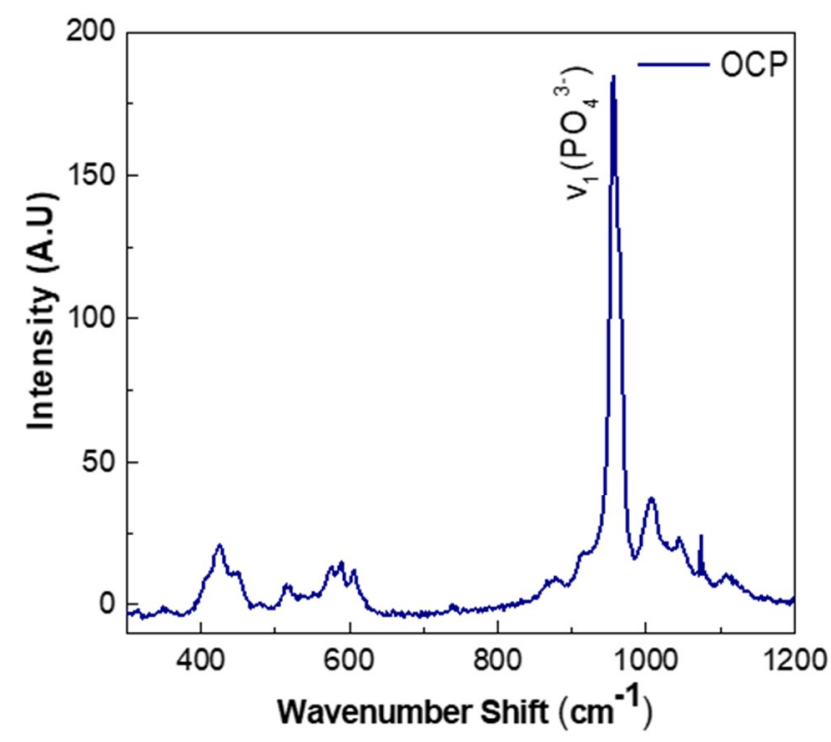

B

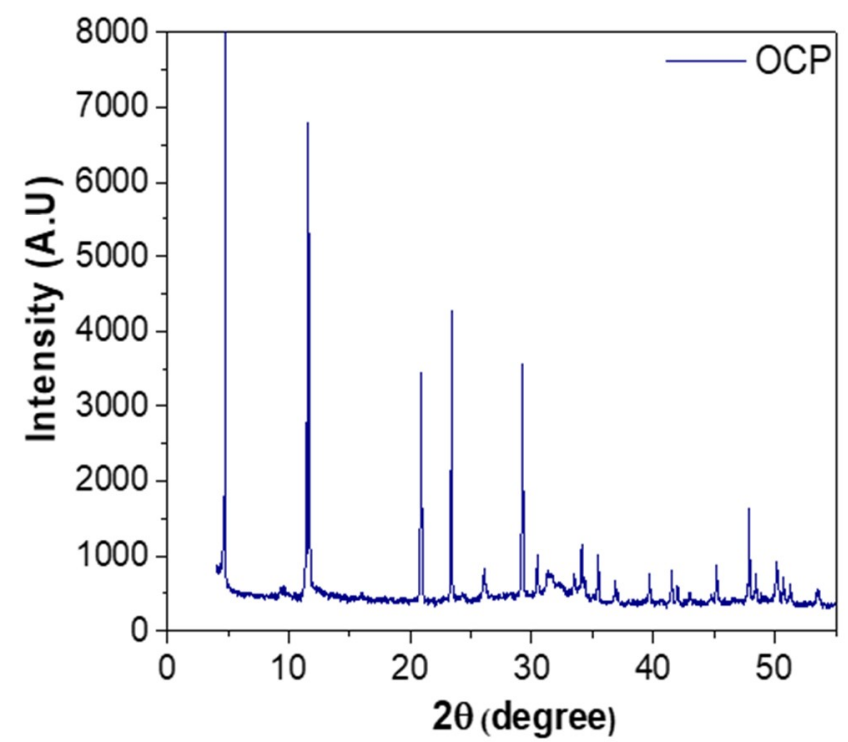

Figure 3. Phase and chemical properties of OCP by XRD and Raman spectra. (A) Raman spectra of OCP. (B) XRD pattern of OCP. 


\subsection{Binding of CEMP1-p3 to OCP Crystals}

Adsorption isotherm analysis was performed to estimate the amount of CEMP1-p3 adsorbed to $\mathrm{OCP}$ crystals, as a function of concentration; $\mathrm{Kd}$ (concentration in which the receptor occupies 50\%) and Bmax (maximum number of binding sites) were determined. Figure 4A shows the CEMP1-p3 adsorption isotherm for OCP crystals; the values of the constants $\mathrm{Kd}$ and Bmax were $0.2883 \pm 0.06(\mu \mathrm{M})$ and $0.04520 \pm 0.3(\mu \mathrm{g})$, respectively. Confocal laser scanning microscopy showed high fluorescence intensity, indicating a high affinity of Alexa fluorine 488-labeled-CEMP1-p3 on the OCP crystal surface (Figure 4B).
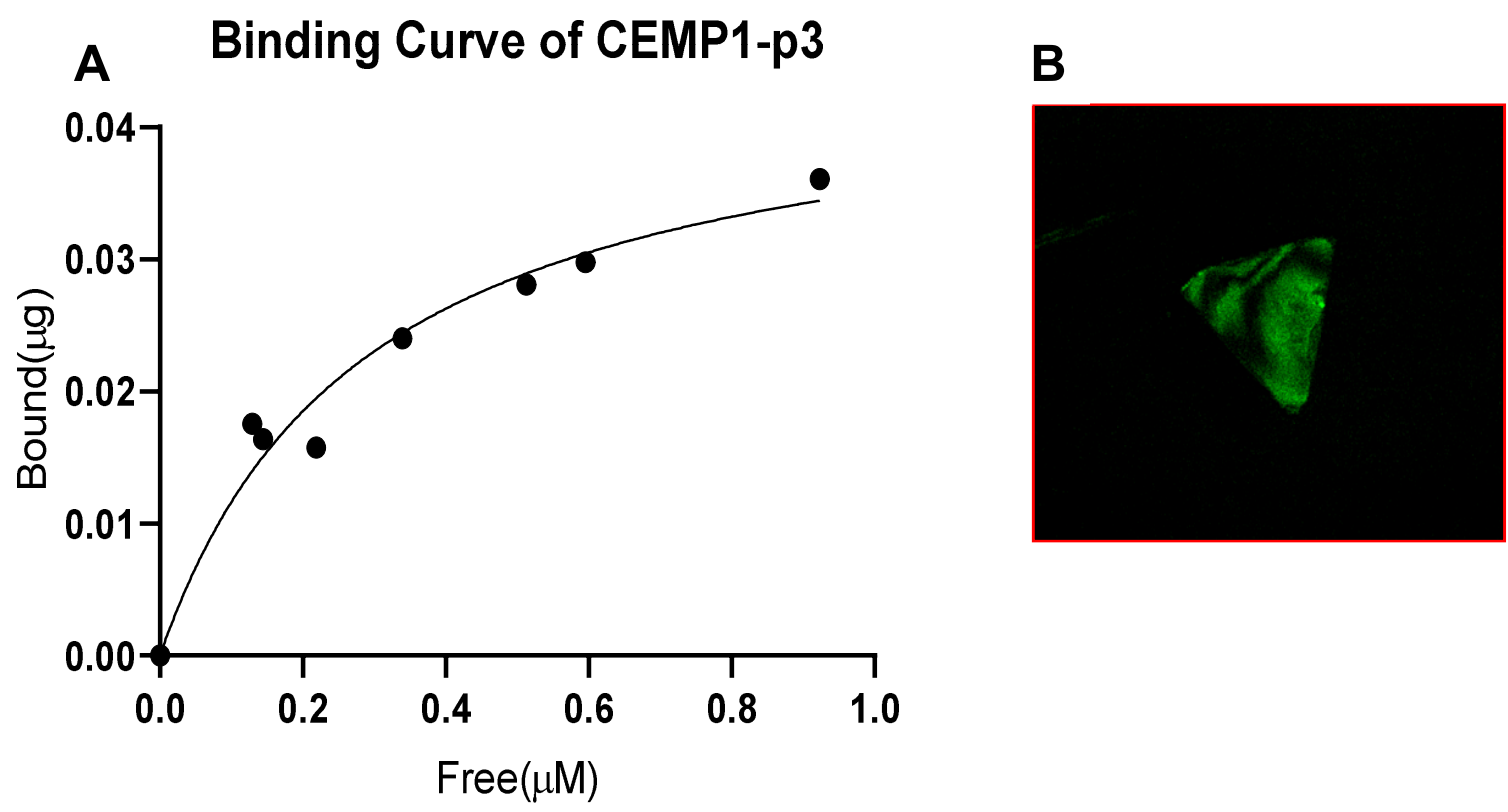

Figure 4. (A) Binding isotherm for CEMP1-p3. The quantity that bounds to the surface of the crystal (Bound, $\mu \mathrm{g}$ ) is plotted as a function of the free concentration (Free, $\mu \mathrm{M}$ ) to obtain the isotherm. (B) CLSM observation of Alexa Fluor 488-labeled CEMP-p3 binding to OCP surface.

\subsection{Octacalcium Phosphate Constant Composition Seeded Growth (CCSG)}

The correlation of the adsorption data with the ability of CEMP1-p3 to regulate crystal growth was determined by constant composition seeded growth assay. This method allowed us to simultaneously investigate the kinetics of OCP crystal growth and the influence of CEMP1-p3 on OCP crystal growth. Several concentrations of CEMP1-p3 were used $(0.6,0.7,1.25,1.75,2.75,3$, and $5 \mu \mathrm{g} / \mathrm{mL})$ in our study. OCP crystal seeds used for the test revealed linear growth. All concentrations of CEMP1-p3 increased OCP crystal growth rates. However, the maximum effect was found with CEMP1-p3 at $2.75 \mu \mathrm{g} / \mathrm{mL}$ concentration, which yields a difference over the $100 \%$ growth rate compared to the control, therefore, CEMP1-p3 was revealed to be a potent OCP crystal growth stimulator (Supplementary Material Figure S2). Scanning electron microscopy showed the morphology of the control sample after seeded growth: triangular structures with an average length of $1.4 \mu \mathrm{m}$ and an average thickness of $264 \mathrm{~nm}$ (Figure 5A). Significant differences were detected in the morphology in the presence of CEMP1-p3 $(2.75 \mu \mathrm{g} / \mathrm{mL}$ concentration) since the crystals changed to laminar structures with an average length and thickness of $800 \pm 2.1 \mathrm{~nm}$ and $57 \pm 1.3 \mathrm{~nm}$, respectively (Figure 5B).

Bright-field TEM and HRTEM micrographs revealed a pinacoid-like structure in the control sample (Figure 5C). The crystal obtained in the presence of CEMP1-p3 at $2.75 \mu \mathrm{g} / \mathrm{mL}$, showed a crystalline hexagonal arrangement (Figure 5D). The FFT analysis shows that the crystalline planes (330) and (004) correspond to the cell of hexagonal HA (inset in Figure 5D). 

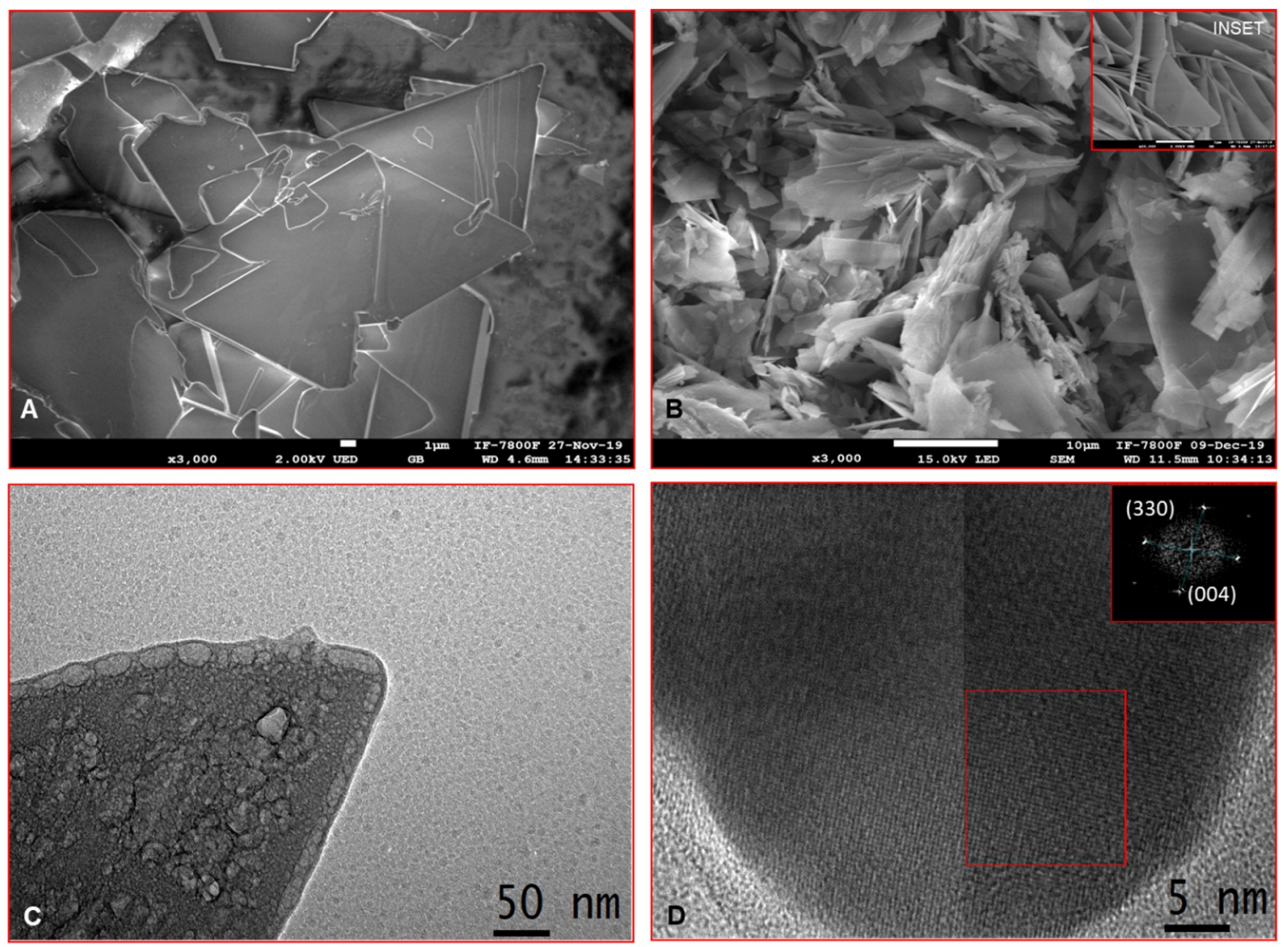

Figure 5. SEM and TEM micrographs of the microstructure and morphology of samples obtained after the CCSG process. (A) Control sample, (B) experimental sample, (C) bright-field TEM micrographs corresponding to OCP (control), (D) HRTEM fringes, and FFT analysis (inset) corresponding to the hydroxyapatite crystal structure (experimental).

A remarkable change was observed in the Fourier-transform infrared spectroscopy (FTIR) bands of the sample obtained after the CCSG process in the presence of CEMP1-p3 at a concentration of $2.75 \mu \mathrm{g}$. The signal was distinguished at $960 \mathrm{~cm}^{-1}$ due to the symmetric vibration of the $\mathrm{PO}_{4}{ }^{3-} \mathrm{v} 1$ group (Figure 6A). The band at $1032 \mathrm{~cm}^{-1}$ corresponded to the asymmetric vibration of the $\mathrm{PO}_{4}{ }^{3-} \mathrm{v}^{3}$ group (Figure 6A). Raman spectra revealed a band at $960 \mathrm{~cm}^{-1}$ due to the $\mathrm{PO}$ vibration associated with the $\mathrm{PO}_{4}{ }^{3-}$ group found in the apatite layer of the OCP crystal. At $920 \mathrm{~cm}^{-1}$ the stretch signal P-(OH) of the $\mathrm{HPO}_{4}{ }^{2-}$ group located between the apatite and hydrated layer of the OCP cell was observed (Figure 6B). The X-ray diffractograms obtained from the OCP crystals treated with CEMP1-p3 showed a space group P63/m, that indicates a complete transformation into HA crystals (ICPDS file No. 72-1243). The presence of broad peaks indicates the precipitation of crystalline HA nanostructures (Figure 6C). Control OCP and CEMP1-p3-OCP treated crystals were indexed with the hkl index. OCP control crystals only showed the OCP crystalline phase, according to ICPDS file No. 44-0778 (Figure 6D). 

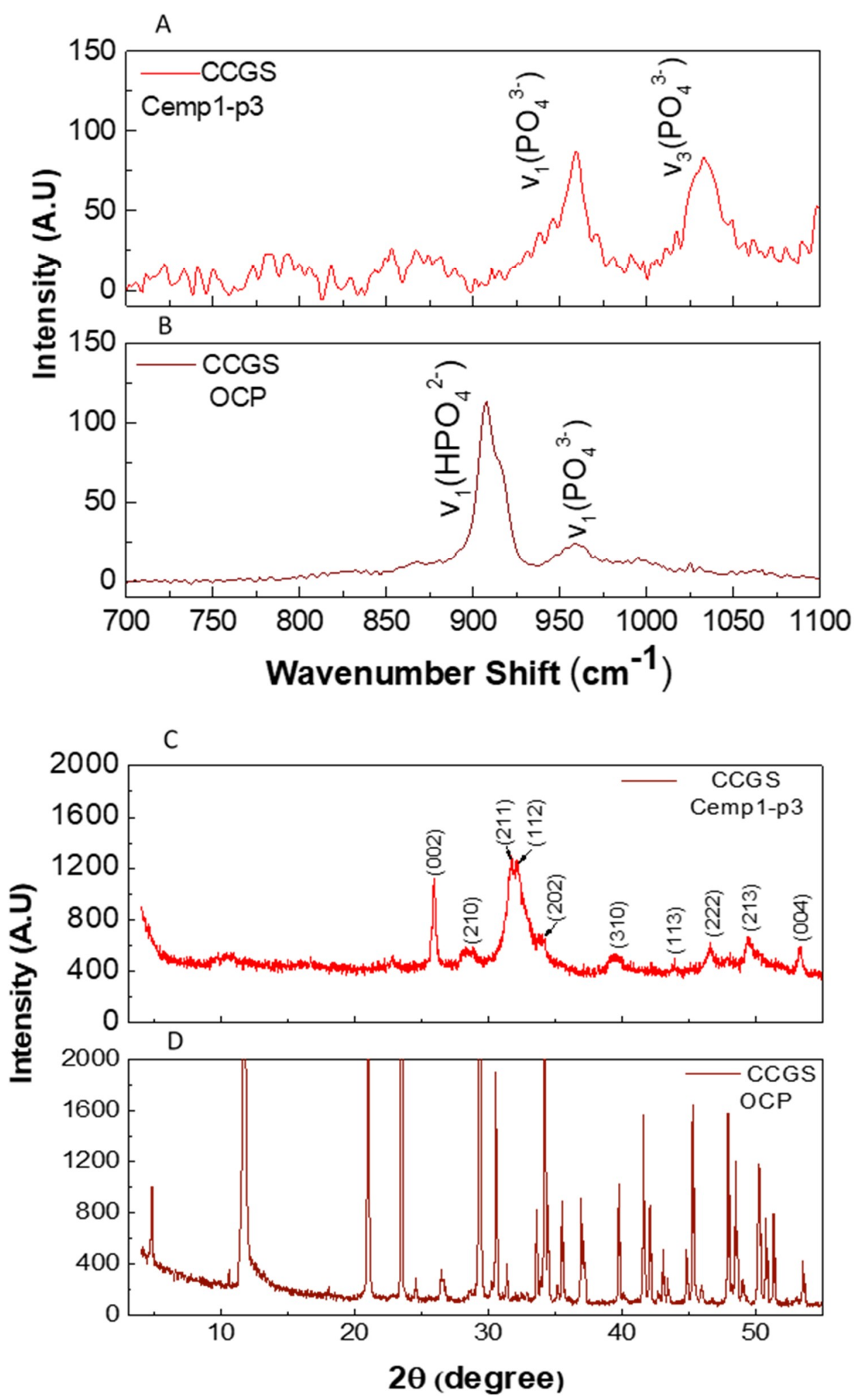

Figure 6. Raman spectra and XRD patterns of samples obtained after CCSG process. (A) Raman spectra corresponds to HA bands (experimental), (B) Raman spectra corresponds to the OCP bands (control), (C) HA crystalline phase (experimental) and (D) Reflections of the crystalline planes of OCP (control). CCGS (constant composition seeded growth). 


\subsection{OCP Growth in Simulated Physiological Buffer}

In order to determine the effect of CEMP1-p3 on OCP crystals in physiological buffer $(20 \mathrm{mM}$ HEPES, $0.2 \mathrm{mM} \mathrm{MgCl}_{2}, 1 \mathrm{mM} \mathrm{CaCl}_{2}, 4 \mathrm{mM} \mathrm{KH}_{2} \mathrm{PO}_{4}, 16 \mathrm{mM} \mathrm{KCl}$, and $4.5 \mathrm{mM} \mathrm{NH}_{4} \mathrm{Cl}$, pH 7.0) control and experimental samples were incubated at $37^{\circ} \mathrm{C}$ for 16 days. Our results showed that control crystals exhibited a platelet-like shape with an average length of $500 \pm 2.3 \mathrm{~nm}$ and a thickness of $100 \pm 2.6 \mathrm{~nm}$ (Figure 7A). The crystals treated with CEMP1-p3 showed an average length of $100 \pm 3.1 \mathrm{~nm}$ and a thickness of $13 \pm 0.6 \mathrm{~nm}$. Homogeneous distribution of the platelet-shaped topography was observed, indicating that specific hydrophobic and electrostatic interactions occurred (Figure 7B). HRTEM analysis of control crystals and FFT analysis showed the (6-42) plane, identified by the interplanar distance, $d=0.184 \mathrm{~nm}$, that corresponded to the OCP phase (Figure 7C). CEMP1-p3-OCP treated crystals showed a hexagonal arrangement according to FFT analysis with planes (330) and (511) that corresponded to the crystal planes of the hydroxyapatite (HA) structure (Figure 7D).
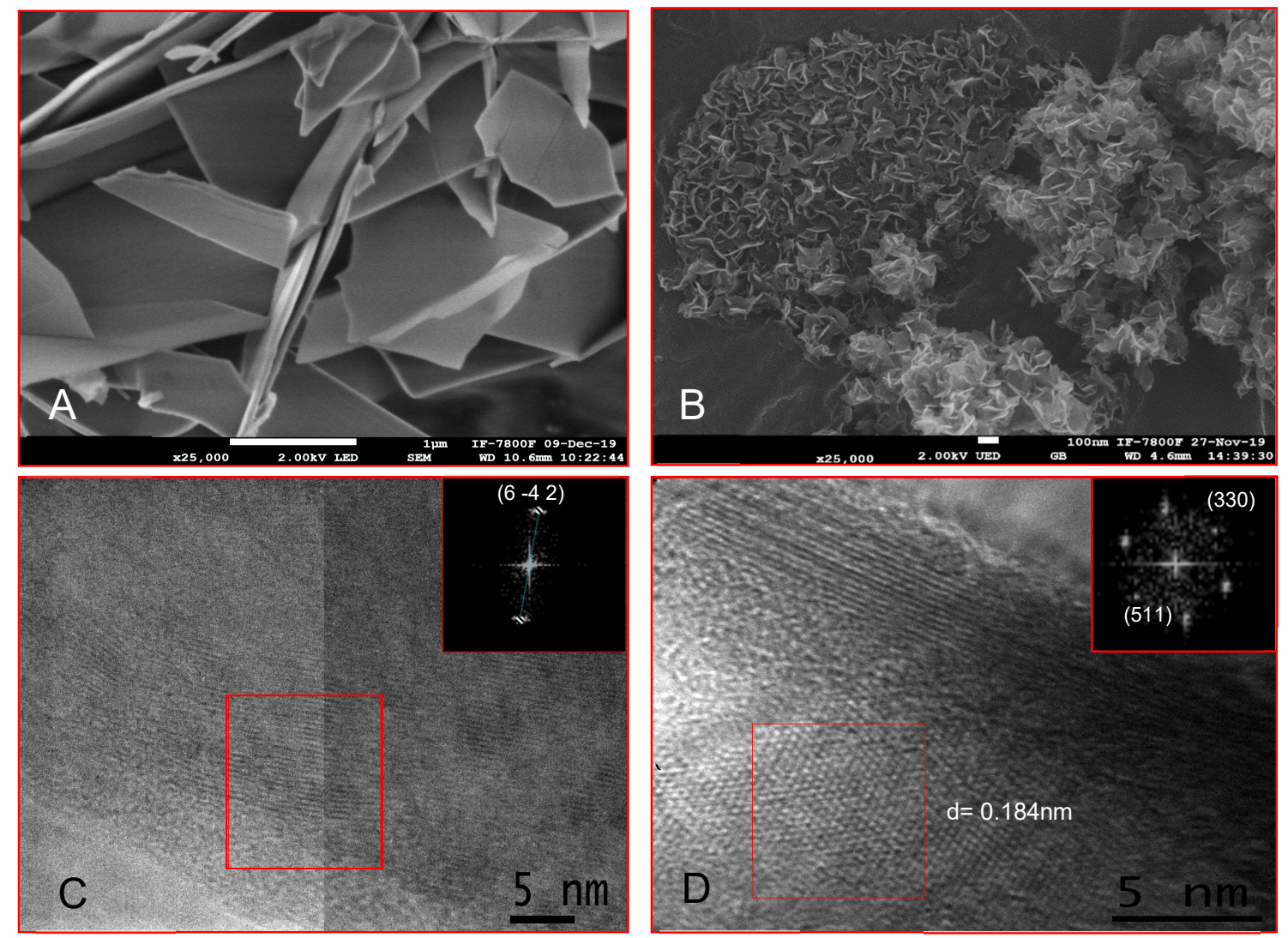

Figure 7. SEM and TEM micrographs of the microstructure and morphology of samples obtained after the SPB assay. (A) SEM images control sample, (B) SEM images experimental sample, (C) bright-field HRTEM micrographs of OCP (control), (D) HRTEM fringes, and FFT analysis corresponding to the HA crystal structure (experimental).

\subsection{Micro Raman Analysis}

The micro Raman spectrum of CEMP1-p3-OCP treatment (Figure 8A), showed vibrations associated with the chemical structure of hexagonal HA. The band observed at $959 \mathrm{~cm}^{-1}(v 1)$ corresponded to the frequency of symmetric vibration of the $\mathrm{PO}_{4}{ }^{3-}$ group and the band at $1034 \mathrm{~cm}^{-1}$ corresponded to the asymmetric vibration of the $\mathrm{PO}_{4}{ }^{3-}$ group (v3), [20-23]. Control crystals showed the characteristic band at $920 \mathrm{~cm}^{-1}$, which according to the OCP chemical composition, corresponds to functional group $\mathrm{HPO}_{4}{ }^{2-}$ (P6) located between the hydrated apatite layer due to the P- $(\mathrm{OH})$ v1 stretch (Figure 8B) [20]. 

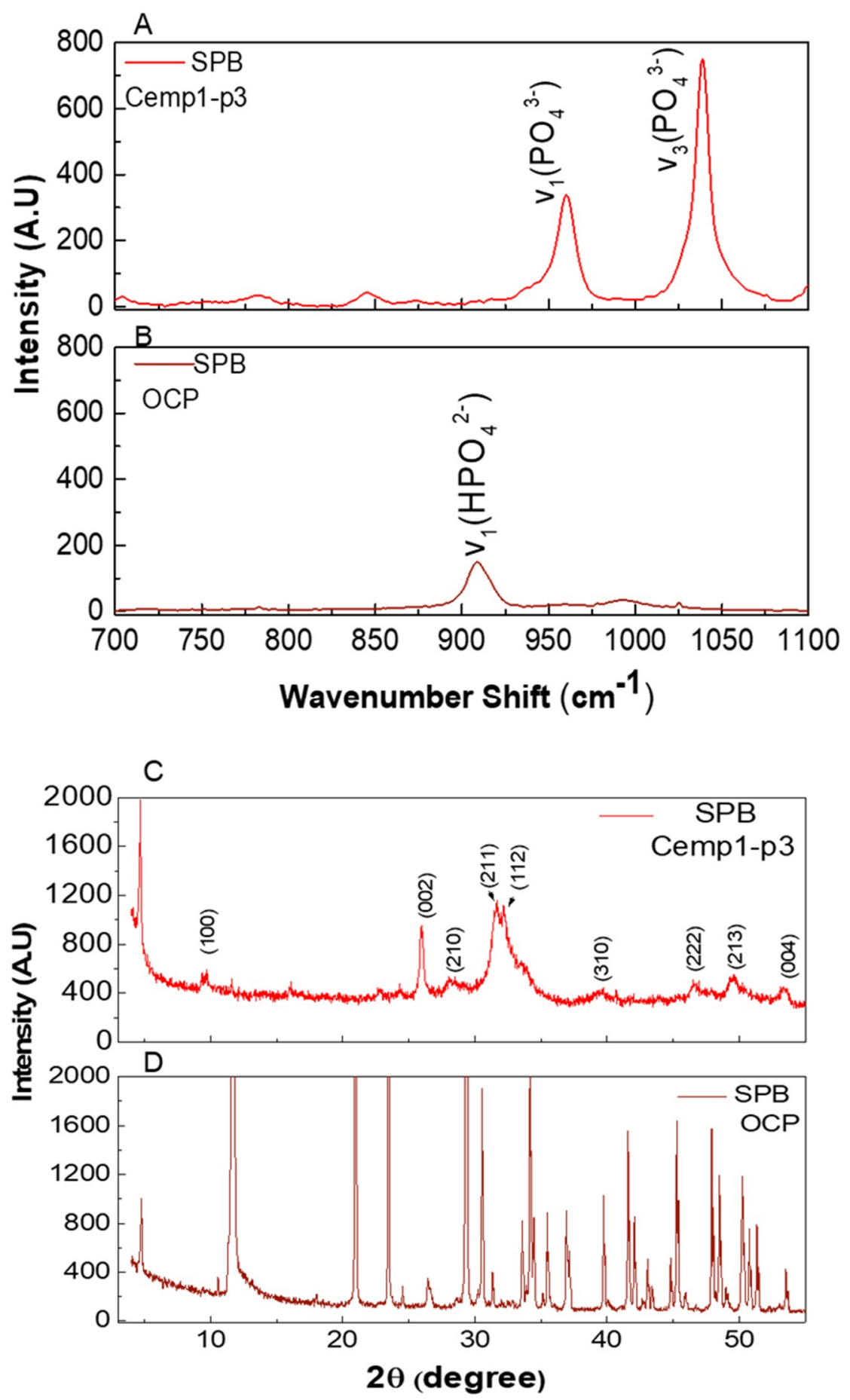

Figure 8. Raman spectra and XRD patterns of control and experimental samples obtained after SPB assay. (A) Raman spectra corresponds to HA bands (experimental), (B) Raman spectra corresponds to the OCP bands (control), (C). HA crystalline phase (experimental) and (D) Reflections of the crystalline planes of OCP (control). (SPB = simulated physiological buffer).

3.6. Powder X-ray Diffraction

The X-ray diffractogram of OCP-CEMP1-p3-treated crystals corresponds to HA crystals (Figure 8C). The control group shows the crystalline phase of OCP (Figure 8D). 


\section{Discussion}

In this study, we synthesized and characterized OCP crystals and investigated the effect of a novel cementum protein 1 derived peptide (CEMP1-p3) on OCP seeds in two media; a constant composition seed growth solution and another solution that simulates physiological conditions, at $\mathrm{pH}$ 7.4. Based on the constant of the adsorption isotherms, we found that there is a high affinity of CEMP1-p3 to OCP crystals. We observed through the laser confocal microscopy that as the peptide concentration in the solution increases, it binds to the surface of the OCP crystal. In silico analysis of CEMP1-p3 showed that it has a hydrophilic character and a positively charged sequence, which could interact with $\mathrm{PO}_{4}{ }^{-}$ and $\mathrm{OH}^{-}$groups of the $\mathrm{OCP}$ face through electrostatic interactions. Carboxylate groups may be able to bind with $\mathrm{Ca}^{2+}$ ions of an OCP crystal face. However, NRM spectroscopy or molecular dynamic studies will be necessary to demonstrate the crystal-peptide interaction [21-25]. From the perspective of crystallization, it is well established that additives: v. gr. macromolecules and peptides, regulate crystal nucleation and growth, therefore, controlling the crystal's properties [26,27]. On the other hand, selective binding of $\mathrm{Ca}^{2+}$ ions in peptides can be characterized by a series of criteria, one of which is that acidic residues are responsible for the coordination of the metal on the first coordination shell.

The supersaturated conditions (CCSG) of ionic and constant physiological solution ( $\mathrm{pH} 7.4$ ) favored OCP seeded growth. These conditions, however, do not support spontaneous phase transformation. Our results demonstrate that the addition of CEMP1-p3 to a constant composition seed growth solution promotes OCP crystal transformation into HA crystals. In this heterogeneous nucleation, CEMP1-p3 probably allowed a favorable thermodynamic state to overcome the energy barriers $[17,28-30]$.

The OCP phase transformation mediated by CEMP1-p3, corroborated by the Raman spectra, showed that the symmetric vibration (vibration $\mathrm{PO}_{4}{ }^{3-} \mathrm{v} 1$ ), was found at the frequency of the hexagonal unit cell of HA. The low intensity of this signal is due to the high sensitivity of the crystalline environment. The frequency and shape of this peak depend on the local environment based on the substitution of anionic groups and the degree of crystallinity. These factors are due to the interactions of the OCP crystals with CEMP1-p3 and are also related to the HA low crystallinity as revealed by the X-ray diffractogram $[19,21,31]$. On the other hand, OCP did not transform to HA under simulated physiological buffer; this could be because the buffer was replaced daily in a static condition [32].

The crystals formed in the presence of CEMP1-p3 showed smaller crystals corresponding both to OCP and HA. In this circumstance, the transformation of OCP to HA crystals in the simulated physiological buffer is speculated to proceed via the initial OCP dissolution particles since OCP has an atomic arrangement similar to that of HA. Therefore, it seems to provide crystal sites that are favorable for adsorption of CEMP1-p3, resulting in local supersaturation, followed by growth and a specific orientation in the maturation of the HA crystal [27,33]. According to the literature, in relation to the interactions that can occur at the organic/inorganic interphase, the amino acids $G, E$, and $Q$ present in the CEMP1-p3 sequence might have selective $\mathrm{Ca}^{2+}$ binding properties [34-37]. Because OCP has an atomic disposition similar to that of HA, CEMP1-p3 changes the structure of OCP by using calcium and phosphate ions obtained from the medium resulting in stable HA crystals. Hence, the importance of CEMP1-p3 to induce OCP crystal transformation to a HA crystal emulating the biomineralization process offers new alternatives in the field of regenerative medicine, particularly of mineralized tissues such as bone, cementum, dentine, and enamel.

\section{Conclusions}

The results of this study found that CEMP1-p3 adsorbs to the surface of OCP crystals and, more importantly, that CEMP1-p3 promotes the phase transformation of OCP crystals to a more stable state of HA under two supersaturated conditions and in physiological solution. The study performed provides new insight into the potential application of CEMP1-p3 on possible biomimetic approaches to generate materials for the repair and regeneration of mineralized tissues, or for materials in the orthopedic or dental area. 
Supplementary Materials: The following are available online at http://www.mdpi.com/2073-4352/10/12/1131/s1, Figure S1: Crystal structure of OCP viewed along the c-axis. Figure S2: Constant Composition Seeded-Growth Assay (CCSG) of OCP in the presence of CEMP1-p3.

Author Contributions: Conceptualization, H.A.; data curation, G.M. and R.H.; formal analysis, G.M. and E.R.; funding acquisition, H.A.; investigation, M.S.; methodology, M.S., R.H. and E.R.; project administration, L.H.; resources, E.R. and C.Z.; software, C.Z.; supervision, G.M. and L.H.; validation, R.H. and C.Z.; writing-original draft, M.S. and H.A.; writing-review and editing, A.W. All authors have read and agreed to the published version of the manuscript.

Funding: This research was funded by DGAPA-PAPIIT, UNAM program. Grant number: IN203920, IN204120, and IN206420 and Maricela Santana Vázquez gratefully acknowledges the fellowship of the POSDOC-UNAM program.

Acknowledgments: The authors acknowledge M.C. Salcedo, C. Zorrilla, R. Hernandez, and C. Magaña for technical assistance in Raman spectroscopy, TEM, SEM microscopy, and powder X-ray diffraction.

Conflicts of Interest: The authors declare no conflict of interest.

\section{References}

1. Hoz, L.; Romo, E.; Sanz, M.; Nunez, J.; Gaitan, L.; Mercado, G.; Arzate, H.; Zeichner-David, M. Cementum protein 1 (CEMP1) induces differentiation by human periodontal ligament cells under three-dimensional culture conditions. Cell Biol. Int. 2011, 36, 129-136. [CrossRef] [PubMed]

2. Chen, X.; Liu, Y.; Yang, J.; Wu, W.; Miao, L.; Yu, Y.; Yang, X.; Sun, W.B. The synthesis of hydroxyapatite with different crystallinities by controlling the concentration of recombinant CEMP1 for biological application. Mater. Sci. Eng. C 2016, 59, 384-389. [CrossRef] [PubMed]

3. Serrano, J.; Romo, E.; Bermúdez, M.; Narayanan, A.S.; Zeichner-David, M.; Santos-Cuevas, C.L.; Arzate, H. Bone Regeneration in Rat Cranium Critical-Size Defects Induced by Cementum Protein 1 (CEMP1). PLoS ONE 2013, 8, e78807. [CrossRef] [PubMed]

4. Montoya, G.; Correa, R.; Arenas, J.; Hoz, L.; Romo, E.; Arroyo, R.; Zeichner-David, M.; Arzate, H. Cementum protein 1-derived peptide (CEMP 1-p1) modulates hydroxyapatite crystal formation in vitro. J. Pept. Sci. 2019, 25, e3211. [CrossRef]

5. Carmona-Rodríguez, B.; Álvarez-Pérez, M.A.; Narayanan, A.S.; Zeichner-David, M.; Reyes-Gasga, J.; Molina-Guarneros, J.A.; García-Hernández, A.L.; Suarez-Franco, J.L.; Gil Chavarría, I.; Villarreal-Ramirez, E.; et al. Human Cementum Protein 1 induces expression of bone and cementum proteins by human gingival fibroblasts. Biochem. Biophys. Res. Commun. 2007, 358, 763-769. [CrossRef]

6. Komaki, M.; Iwasaki, K.; Arzate, H.; Narayanan, A.S.; Izumi, Y.; Morita, I. Cementum protein 1 (CEMP1) induces a cementoblastic phenotype and reduces osteoblastic differentiation in periodontal ligament cells. J. Cell. Physiol. 2012, 227, 649-657. [CrossRef]

7. Villarreal-Ramirez, E.; Moreno, A.; Mas-Oliva, J.; Chávez-Pacheco, J.L.; Narayanan, A.S.; Gil-Chavarría, I.; Zeichner-David, M.; Arzate, H. Characterization of recombinant human cementum protein 1 (hrCEMP1): Primary role in biomineralization. Biochem. Biophys. Res. Commun. 2009, 384, 49-54. [CrossRef]

8. Correa, R.; Arenas, J.; Montoya, G.; Hoz, L.; López, S.; Salgado, F.; Arroyo, R.; Salmeron, N.; Romo, E.; Zeichner-David, M.; et al. Synthetic cementum protein 1-derived peptide regulates mineralization in vitro and promotes bone regeneration in vivo. FASEB J. 2018, 33, 1167-1178. [CrossRef]

9. Hench, L.L. Bioceramics. J. Am. Ceram. Soc. 2005, 81, 1705-1728. [CrossRef]

10. Zhang, P.; Hong, Z.; Yu, T.; Chen, X.; Jing, X. In vivo mineralization and osteogenesis of nanocomposite scaffold of poly(lactide-co-glycolide) and hydroxyapatite surface-grafted with poly(l-lactide). Biomaterials 2009, 30, 58-70. [CrossRef]

11. Vallet-Regí, M.; Navarrete, D.A. Chapter 1: Biological Apatites in Bone and Teeth. In Nanoceramics in Clinical Use: From Materials to Applications, 2nd ed.; Nanoscience \& Nanotechnology Series; Royal Society of Chemistry: London, UK, 2015; pp. 1-29. [CrossRef]

12. Srivastava, S. Sorption of Divalent Metal Ions from Aqueous Solution by Oxidized Carbon Nanotubes and Nanocages: A Review. Adv. Mater. Lett. 2013, 4, 2-8. [CrossRef]

13. Sugiura, Y.; Saito, Y.; Endo, T.; Makita, Y. Effect of the Ionic Radius of Alkali Metal Ions on Octacalcium Phosphate Formation via Different Substitution Modes. Cryst. Growth Des. 2019, 19, 4162-4171. [CrossRef] 
14. Kamitakahara, M.; Ohtoshi, N.; Kawashita, M.; Ioku, K. Spherical porous hydroxyapatite granules containing composites of magnetic and hydroxyapatite nanoparticles for the hyperthermia treatment of bone tumor. J. Mater. Sci. Mater. Med. 2016, 27, 1-7. [CrossRef] [PubMed]

15. Oktar, F.N.; Gökçe, H.; Gunduz, O.; Sahin, Y.; Ağaoğullari, D.; Turner, I.; Ozyegin, L.; Ben-Nissan, B. Bioceramic Production from Giant Purple Barnacle (Megabalanus tintinnabulum). Key Eng. Mater. 2014, 631, 137-142. [CrossRef]

16. Rao, A.; Roncal-Herrero, T.; Schmid, E.; Drechsler, M.; Scheffner, M.; Gebauer, D.; Kröger, R.; Cölfen, H. On Biomineralization: Enzymes Switch on Mesocrystal Assembly. ACS Central Sci. 2019, 5, 357-364. [CrossRef]

17. Mann, S.; Archibald, D.D.; Didymus, J.M.; Douglas, T.; Heywood, B.R.; Meldrum, F.C.; Reeves, N.J. Crystallization at Inorganic-organic Interfaces: Biominerals and Biomimetic Synthesis. Science 1993, 261, 1286-1292. [CrossRef]

18. Tomson, M.B.; Nancollas, G.H.; Tamm, G.R.; Cobb, J.S. Mineralization Kinetics: A Constant Composition Approach. Science 1978, 200, 1059-1060. [CrossRef]

19. Fowler, B.O.; Markovic, M.; Brown, W.E. Octacalcium phosphate. 3. Infrared and Raman vibrational spectra. Chem. Mater. 1993, 5, 1417-1423. [CrossRef]

20. Tao, J.; Battle, K.C.; Pan, H.; Salter, E.A.; Chien, Y.-C.; Wierzbicki, A.; De Yoreo, J.J. Energetic basis for the molecular-scale organization of bone. Proc. Natl. Acad. Sci. USA 2014, 112, 326-331. [CrossRef]

21. Timchenko, P.E.; Timchenko, E.V.; Pisareva, E.V.; Vlasov, M.Y.; Volova, L.T.; Frolov, O.O.; Kalimullina, A.R. Experimental studies of hydroxyapatite by Raman spectroscopy. J. Opt. Technol. 2018, 85, 130-135. [CrossRef]

22. Santana-Vázquez, M.; Estevez, O.; Ascencio-Aguirre, F.; Mendoza-Cruz, R.; Bazán-Díaz, L.; Zorrila, C.; Herrera-Becerra, R. Tannic acid assisted synthesis of flake-like hydroxyapatite nanostructures at room temperature. Appl. Phys. A 2016, 122, 868. [CrossRef]

23. Azzopardi, P.V.; O'Young, J.; Lajoie, G.; Karttunen, M.; Goldberg, H.A.; Hunter, G.K. Roles of Electrostatics and Conformation in Protein-Crystal Interactions. PLoS ONE 2010, 5, e9330. [CrossRef] [PubMed]

24. Farmanesh, S.; Ramamoorthy, S.; Chung, J.; Asplin, J.R.; Karande, P.; Rimer, J.D. Specificity of Growth Inhibitors and their Cooperative Effects in Calcium Oxalate Monohydrate Crystallization. J. Am. Chem. Soc. 2013, 136, 367-376. [CrossRef] [PubMed]

25. Khalili, M.; Saunders, J.A.; Liwo, A.; Ołdziej, S.; Scheraga, H.A. A united residue force-field for calcium-protein interactions. Protein Sci. 2009, 13, 2725-2735. [CrossRef] [PubMed]

26. Antonakos, A.; Liarokapis, E.; Leventouri, T. Micro-Raman and FTIR studies of synthetic and natural apatites. Biomaterials 2007, 28, 3043-3054. [CrossRef] [PubMed]

27. Lotsari, A.; Rajasekharan, A.K.; Halvarsson, M.; Andersson, M. Transformation of amorphous calcium phosphate to bone-like apatite. Nat. Commun. 2018, 9, 1-11. [CrossRef]

28. Jamalian, A.; Sneekes, E.-J.; Dekker, L.J.M.; Ursem, M.; Luider, T.M.; Burgers, P. (Peter) Dimerization of Peptides by Calcium Ions: Investigation of a Calcium-Binding Motif. Int. J. Proteom. 2014, 2014, 1-8. [CrossRef]

29. Habraken, W.J.E.M.; Tao, J.; Brylka, L.J.; Friedrich, H.; Bertinetti, L.; Schenk, A.S.; Verch, A.; Dmitrovic, V.; Bomans, P.H.H.; Frederik, P.M.; et al. Ion-association complexes unite classical and non-classical theories for the biomimetic nucleation of calcium phosphate. Nat. Commun. 2013, 4, 1507. [CrossRef]

30. Gower, L.B. Biomimetic Model Systems for Investigating the Amorphous Precursor Pathway and Its Role in Biomineralization. Chem. Rev. 2008, 108, 4551-4627. [CrossRef]

31. Dove, P.M.; Han, N.; Wallace, A.F. Systematic dependence of kinetic and thermodynamic barriers to homogeneous silica nucleation on $\mathrm{NaCl}$ and amino acids. J. Mater. Res. 2019, 34, 442-455. [CrossRef]

32. Ito, N.; Kamitakahara, M.; Yoshimura, M.; Ioku, K. Importance of nucleation in transformation of octacalcium phosphate to hydroxyapatite. Mater. Sci. Eng. C 2014, 40, 121-126. [CrossRef] [PubMed]

33. Seeman, N.C.; Belcher, A.M. Emulating biology: Building nanostructures from the bottom up. Proc. Natl. Acad. Sci. USA 2002, 99, 6451-6455. [CrossRef] [PubMed]

34. Penel, G.; Leroy, G.; Rey, C.; Bres, E. MicroRaman Spectral Study of the $\mathrm{PO}_{4}$ and $\mathrm{CO}_{3}$ Vibrational Modes in Synthetic and Biological Apatites. Calcif. Tissue Int. 1998, 63, 475-481. [CrossRef] [PubMed]

35. Gazit, E. Self-assembled peptide nanostructures: The design of molecular building blocks and their technological utilization. Chem. Soc. Rev. 2007, 36, 1263-1269. [CrossRef] [PubMed] 
36. Qiu, S.R.; Wierzbicki, A.S.; Orme, C.A.; Cody, A.M.; Hoyer, J.R.; Nancollas, G.H.; Zepeda, S.; De Yoreo, J.J. Molecular modulation of calcium oxalate crystallization by osteopontin and citrate. Proc. Natl. Acad. Sci. USA 2004, 101, 1811-1815. [CrossRef] [PubMed]

37. Wang, J.; Liu, K.; Xing, R.; Yan, X. Peptide self-assembly: Thermodynamics and kinetics. Chem. Soc. Rev. 2016, 45, 5589-5604. [CrossRef]

Publisher's Note: MDPI stays neutral with regard to jurisdictional claims in published maps and institutional affiliations.

(C) 2020 by the authors. Licensee MDPI, Basel, Switzerland. This article is an open access article distributed under the terms and conditions of the Creative Commons Attribution (CC BY) license (http://creativecommons.org/licenses/by/4.0/). 